\title{
OKREŚLENIE POZIOMU ŚWIADOMOŚCI KORZYSTANIA Z WYBRANYCH SKEADOWYCH SZTUCZNEGO ŚRODOWISKA MILITARNEGO
}

\begin{abstract}
W prezentowanym artykule autorzy omawiają zagadnienia „sztucznego środowiska militarnego" przez pryzmat wykorzystania jego osiągnięć do podniesienia standardu i komfortu życia w obiektach niczym nieprzypominających techniki i sprzętu wojskowego oraz inżynieryjnych budowli obronnych. Pierwowzoru środowiska militarnego należy upatrywać w czasie, kiedy człowiek zbudował pierwszą palisadę okalającą jego siedlisko. Modyfikując przez lata siedlisko i miejsce jego położenia, często przenosząc je w obce mu środowisko, rozumiane jako dotychczas nie zagospodarowane, technizował je coraz bardziej, stosownie do poziomu społeczno-gospodarczego. Na tak opisywane „sztuczne” środowisko autorzy spojrzą poprzez pryzmat zagadnień i kierunków dociekań z militarnowojskowego punktu widzenia. Śledząc historię wojskowości nie można oprzeć się wrażeniu, że walczący ewoluując od woja poprzez rycerza do żołnierza, zawsze dbali nie tylko o rozwój sztuki wojennej, ale również wiele uwagi poświęcali orężu, mobilnym i statycznym urządzeniom i budowlom militarnym. Nie jest żadną tajemnicą, że zanim jakikolwiek wynalazek zostanie wykorzystany przez „,cywili” najpierw jego przydatność badają wojskowi w celu określenia jego funkcjonalności do szeroko rozumianej obronności państwa.

Historię wykorzystania militarnych osiągnięć i wprowadzenie ich do życia cywilnego przedstawiono w niniejszym artykule w oparciu o specjalistyczną i branżową literaturę przedmiotu oraz prezentując wyniki badań przeprowadzonych na grupach celowych wyodrębnionych z regionów, które statystycznemu Polakowi kojarzą się z szeroko rozumianą obronnością państwa.
\end{abstract}

Słowa kluczowe: środowisko naturalne człowieka, sztuczne środowisko militarne

\section{WPROWADZENIE}

Każde starcie zwaśnionych odbywało się u zarania dziejów na „ubitej ziemi” z czasem przenosząc się na inne teatry działań takie jak: morski, powietrzny i wreszcie kosmiczny. Można zatem stwierdzić, że pierwsze konflikty rozstrzygane były w naturalnym środowisku człowieka. Tak jak ewoluowała sztuka wojenna zmieniało się również środowisko

\footnotetext{
${ }^{1}$ Dr Hanna Sommer (autor korespondencyjny), Katedra Nauk Humanistycznych, Wydział Zarządzania, Politechnika Rzeszowska, Al. Powstańców Warszawy 8, 35-959 Rzeszów; e-mail: hansom@prz.edu.pl

2 Dr inż. Grzegorz Zakrzewski, Instytut Bezpieczeństwa Narodowego, Wydział Nauk o Zarządzaniu i Bezpieczeństwie, Akademia Pomorska w Słupsku, ul. Arciszewskiego 22a, 76-200 Słupsk; e-mail: grzegorz.zakrzewski@apsl.edu.pl
} 
naturalne człowieka gdzie były przenoszone działania zbrojne. Do powstania sztucznego środowiska na pewno przyczyniła się również człowiecza cecha ekspansji terytorialnej przez podbijanie nowych terenów/terytoriów i przestrzeni kosmicznej. Lot Jurija Aleksiejewicza Gagarina na statku kosmicznym „Wostok 1”3 w dniu 12 kwietnia 1961 roku uznaje się za datę udanego pobytu człowieka w kosmosie. Znawcy przedmiotu nie wypowiadają się jednoznacznie na temat daty powstania sztucznego środowiska człowieka, nadzwyczaj zgodni są natomiast co do definicji. Autorzy na potrzeby artykułu posługują się definicją podaną przez P. Żukowskiego. ,»Sztuczne« środowisko człowieka powstało w toku działań człowieka wspomaganego techniką (technologią), której niedoskonały i ograniczony rozwój spowodował jednostronność tego środowiska. Konsekwencją tej jednostronności jest fakt, że człowiek staje się niewolnikiem cywilizacji, niewolnikiem stworzonego przez siebie środowiska, które staje się dla niego coraz bardziej uciążliwe. Uciążliwości te są o różnych rozmiarach i wynikają z pewnych określonych cech dominujących w danym typie środowiska"4.

Żukowski wyróżnia trzy typy „sztucznego” środowiska, które przedstawiono na rys. $1^{5}$.

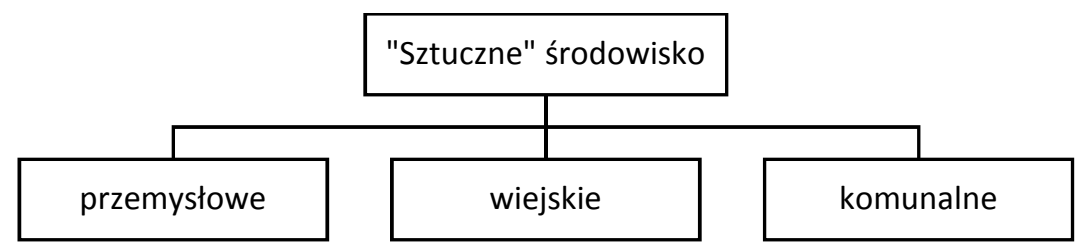

Rys. 1. Trzy typy „sztucznego” 'środowiska

Źródło: opracowano na podstawie: P. Żukowski, Wspótczesne problemy ochrony środowiska człowieka, Szczecin 1985.

Nie jest celem autorów dokładne charakteryzowanie wymienionych środowisk. Uważny czytelnik intuicyjnie potrafi je opisać. Ten podział ,sztucznych” środowisk G. Zakrzewski uznał za niewystarczający i zaproponował uzupełnienie o środowisko militarne ${ }^{6}$.

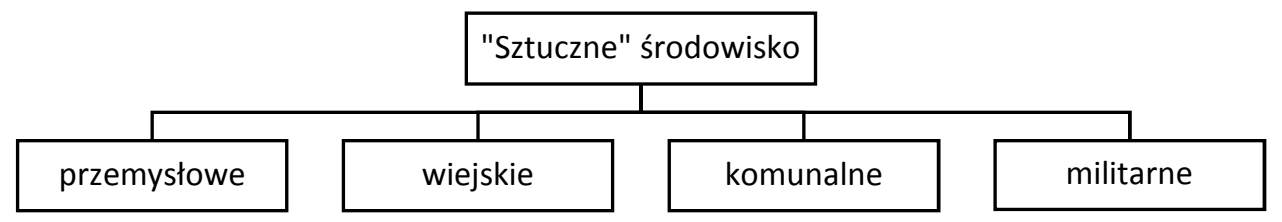

Rys. 2. Cztery typy „,sztucznego” środowiska

Źródło: opracowanie własne na podstawie: G. Zakrzewski, Czy sztuczne środowisko militarne jest faktem?, „Przegląd Morski” 1995/12

\footnotetext{
${ }^{3}$ http://www.szkolnictwo.pl/szukaj,Jurij_Gagarin (dostęp: 12.01.2017 r.).

${ }^{4}$ P. Żukowski, Wspótczesne problemy ochrony środowiska człowieka, Szczecin 1985, s. 37.

5 Tamże, s. 38.

${ }^{6}$ G. Zakrzewski, Czy sztuczne środowisko militarne jest faktem?, „Przegląd Morski” 1995/12, s. 40.
} 
W dalszej części artykułu przedstawiono podział „sztucznego” środowiska militarnego.

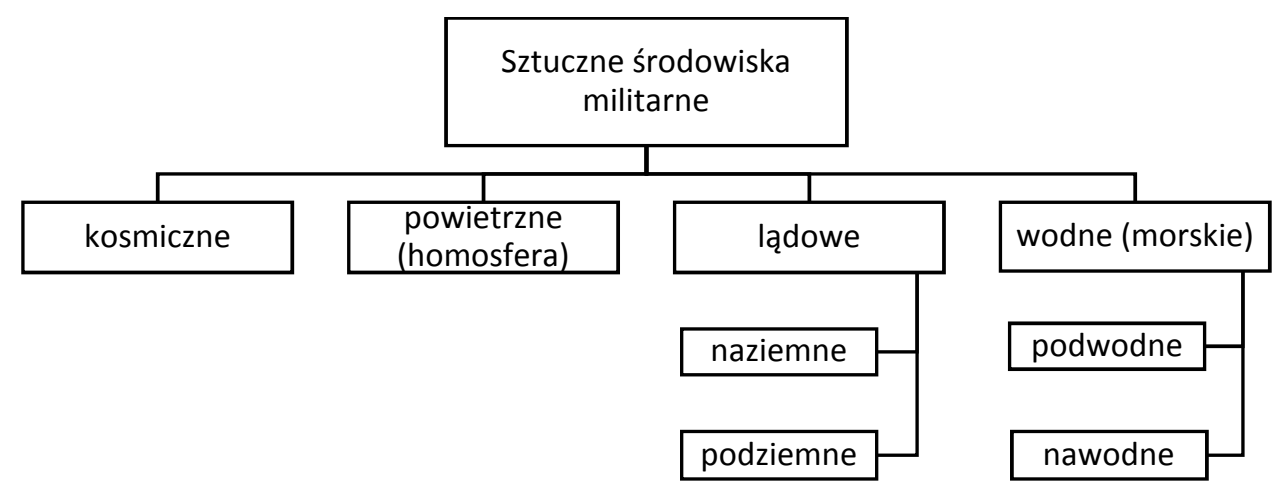

Rys. 3 Podział sztucznego środowiska militarnego

Źródło: opracowanie własne na podstawie: G. Zakrzewski, Czy sztuczne środowisko...

Środowisko militarne to również poligony wojskowe, gdzie prowadzą szkolenie różne Rodzaje Sił Zbrojnych RP. Poligon wojskowy - to wojskowy teren zamknięty używany do ćwiczeń i manewrów wojskowych jak też przeprowadzania testów broni. Pochodzenie słowa z języka angielskiego (polygon) - zamknięty obszar na potrzeby wojska w kształcie wielokąta. Pierwsze poligony wojskowe zaczęto tworzyć na potrzeby armii pruskiej pod koniec XVIII wieku. Na potrzeby niniejszego artykułu przyjęto uproszczony podział poligonów. Za kryterium podziału przyjęto rodzaj środowiska, w którym prowadzi się szkolenie sił i środków danego rodzaju Sił Zbrojnych. Zatem można zaproponować podział poligonów na:

a) Poligony morskie - są wyznaczone w rozporządzeniu Ministra Obrony Narodowej z dnia 3 kwietnia 2014 roku $^{7}$. Ostrzeżenia nawigacyjne aktualizowane są na bieżąco przez operatora dyżurnego Krajowego Koordynatora Ostrzeżeń Nawigacyjnych. Na stronie BHMW są one prezentowane w formie plików PDF. Zawartość tych plików uwzględnia treść danego ON rozpowszechnianą zarówno do instytucji cywilnych, jak i wojskowych (możliwość druku wybranej strony). Bieżące ON są zamieszczane w oddzielnych panelach obejmujących:

- ON Lokalne BHMW - odniesione do użytkowników akwenów Zatoki Gdańskiej,

- ON Brzegowe BHMW - dotyczące wszystkich użytkowników wód polskiego wybrzeża,

- ON Subarea - ogłaszane dla wszystkich statków znajdujących się na wodach Morza Bałtyckiego $^{8}$.

\footnotetext{
${ }^{7}$ Rozporządzenie Ministra Obrony Narodowej z dnia 3 kwietnia 2014 r. w sprawie stref zamkniętych dla żeglugi i rybołówstwa na obszarach morskich Rzeczypospolitej Polskiej (Dz.U. z 2014 r., poz. 482).

${ }^{8}$ http://www.bhmw.mw.mil.pl/index.php?akcja=ostrzezenia (dostęp: 11.01.2017 r.).
} 
b) Poligony lądowe. O poligonach lądowych na stronie Ministerstwa Obrony Narodowej brak jest informacji. Dlatego autorzy przedstawili tylko wybrane największe poligony (pełna informacja ${ }^{9}$ ).

c) Poligony lotnicze i artylerii przeciwlotniczej znajdują się w przestrzeni powietrznej nad poligonami lądowymi i morskimi.

Tabela 1. Wybrane poligony lądowe

\begin{tabular}{|c|c|c|c|}
\hline Poligon & Lokalizacja & Status & Opis \\
\hline Biedrusko & $\begin{array}{l}\text { na północ od miasta } \\
\text { Poznań, między Biedru- } \\
\text { skiem a Chludowem }\end{array}$ & czynny & $\begin{array}{l}\text { Poligon wojsk lądowych, wykorzystywany głównie } \\
\text { przez Centrum Szkolenia Wojsk Lądowych im. } \\
\text { Hetmana Polnego Koronnego Stefana Czarnieckie- } \\
\text { go jako poligon czołgowy. }\end{array}$ \\
\hline Czarne & $\begin{array}{l}\text { na północ i południowy } \\
\text { zachód od miasta Czarne }\end{array}$ & czynny & Poligon czołgowy. \\
\hline $\begin{array}{l}\text { Drawsko } \\
\text { Pomorskie }\end{array}$ & $\begin{array}{l}\text { na południe od miasta } \\
\text { Drawsko Pomorskie }\end{array}$ & czynny & $\begin{array}{l}\text { Centrum Szkolenia Wojsk Lądowych, najnowocze- } \\
\text { śniej wyposażony poligon wojsk lądowych i lotni- } \\
\text { czych, często wykorzystywany do ćwiczeń w ra- } \\
\text { mach NATO. }\end{array}$ \\
\hline Jagodne & $\begin{array}{l}\text { w lasach łukowskich, na } \\
\text { północny zachód od } \\
\text { miasta Łuków }\end{array}$ & czynny & $\begin{array}{l}\text { Poligon lądowy, służy jako poligon akademicki } \\
\text { Wyższej Szkoły Oficerskiej Sił Powietrznych. }\end{array}$ \\
\hline $\begin{array}{l}\text { Ustka- } \\
\text { Wicko } \\
\text { Morskie }\end{array}$ & $\begin{array}{lr}\text { na wybrzeżu, } & \text { między } \\
\text { miejscowościami } & \text { Jaro- } \\
\text { sławiec } \text { i } \text { Ustka } & \\
\end{array}$ & czynny & $\begin{array}{l}\text { Poligon sił powietrznych, wojsk przeciwlotniczych } \\
\text { a także Marynarki Wojennej. }\end{array}$ \\
\hline Nadarzyce & $\begin{array}{l}\text { na północny zachód od } \\
\text { wsi Nadarzyce }\end{array}$ & czynny & $\begin{array}{l}\text { Poligon lotniczy (największy w Europie), wyposa- } \\
\text { żony w bombowe pole robocze. Dawne lotnisko } \\
\text { i stojące w jego okolicy wycofane z użytku samolo- } \\
\text { ty wykorzystywane są jako cele. }\end{array}$ \\
\hline Nowa Dęba & $\begin{array}{l}\text { na wschód od miasta } \\
\text { Nowa Dęba }\end{array}$ & czynny & Poligon wojsk lądowych. \\
\hline
\end{tabular}

Źródło: opracowanie własne na podstawie http://www.wikiwand.com/pl/Poligon_wojskowy (dostęp: 11.01.2017 r.).

Na mapie 1 widać zaznaczony obszar wyłącznej strefy ekonomicznej (obszar ok. 22,5 tys. $\mathrm{km}^{2}$ ), nad którym sprawowana jest administracja morska. Organami administracji morskiej są: minister właściwy do spraw gospodarki morskiej (jako naczelny organ administracji morskiej), dyrektorzy urzędów morskich (jako terenowe organy administracji morskiej $)^{10}$.

\footnotetext{
9 http://www.wikiwand.com/pl/Poligon_wojskowy (dostęp: 11.01.2017 r.).

${ }_{10}$ Zob. art. 38 ustawy z dnia 21 marca 1991 r. o obszarach morskich Rzeczypospolitej Polskiej i administracji morskiej (tekst jedn. Dz.U. z 2016 r., poz. 2145 ze zm.).
} 


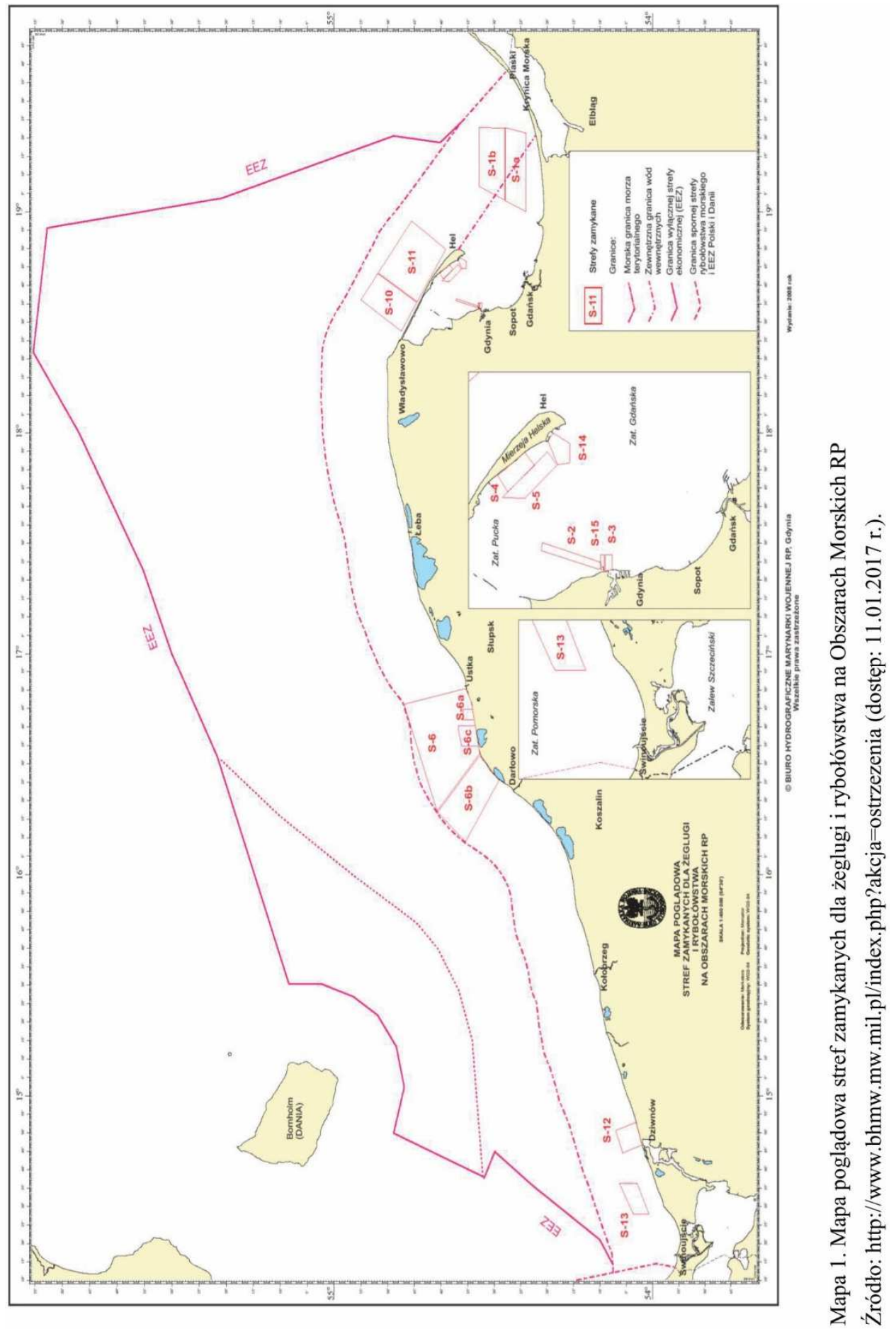


W cytowanej ustawie ustawodawca przewidział tworzenie elementów sztucznego środowiska (budowa farm wiatrowych).

W sztucznych środowiskach militarnych ich użytkownicy wytwarzają sztucznie warunki klimatyczne niezbędne do stacjonowania siły żywej, eksploatowanej techniki wojskowej i przetrzymywania zapasów ${ }^{11}$. Ogólny podział przestrzeni wymagających stworzenia sztucznego klimatu przedstawiano na rys. 4.

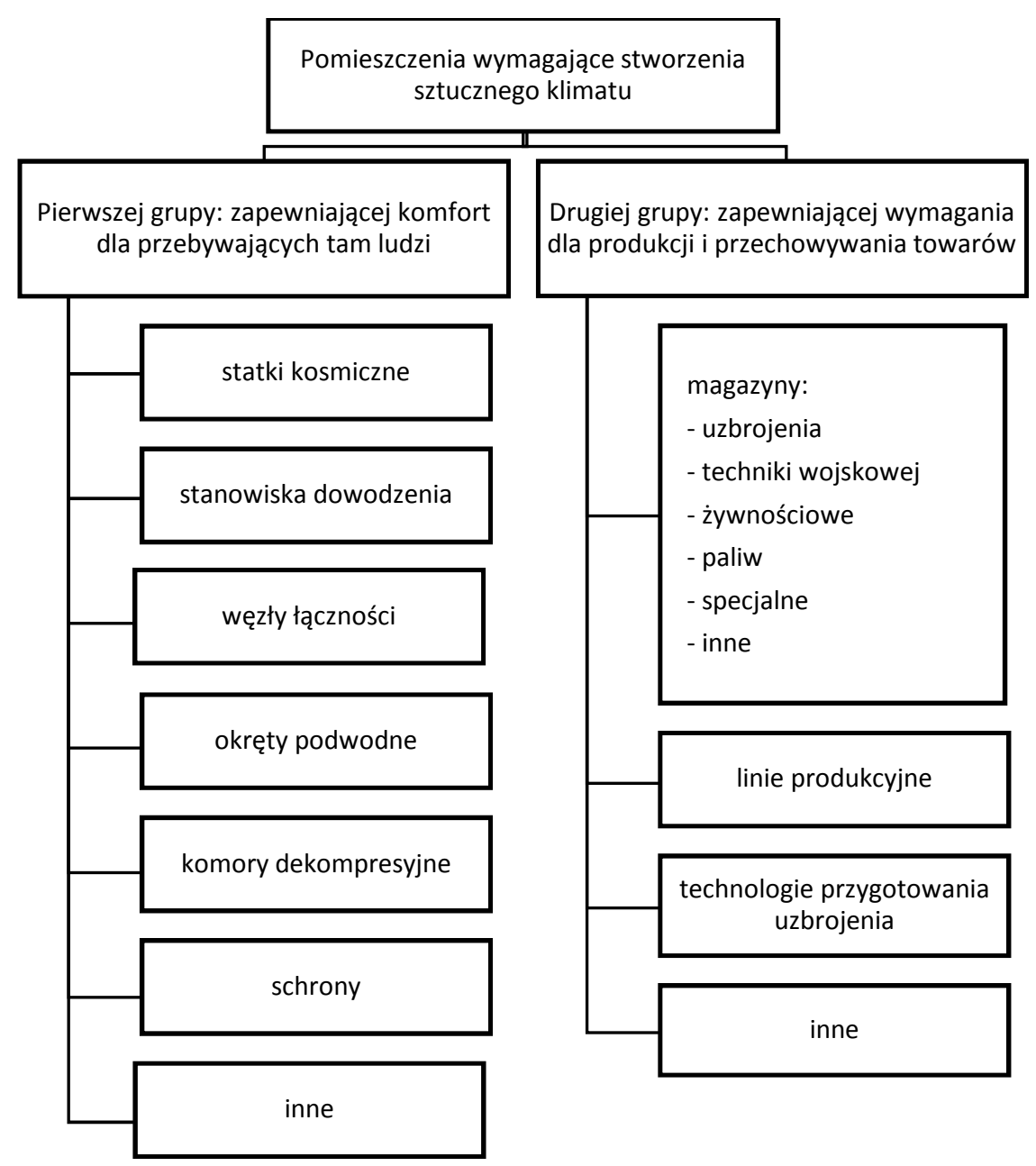

Rys. 4. Ogólny podział przestrzeni wymagających stworzenia sztucznego klimatu

Źródło: opracowanie własne na podstawie: G. Zakrzewski, Czy sztuczne środowisko...

${ }^{11}$ M. Kaczmarek, M. Stokwisz, Wentylacja $w$ budowli specjalnej, WAT, Konferencja Naukowo-Techniczna na temat „Inżynieria środowiska w budownictwie”, Hel-Jurata 1993, s. 18-19. 
Problem wytwarzania i utrzymywania właściwych warunków mikroklimatycznych wiąże się z potrzebą izolowania przestrzeni pomieszczeń przed bezpośrednim wpływem niekorzystnych warunków atmosferycznych lub ich braku (np. przestrzeń okrętu podwodnego). W pomieszczeniach pierwszej grupy celem działania jest zagwarantowanie komfortu klimatycznego dla przebywających tam osób, natomiast w pomieszczeniach drugiej grupy - jakość produkowanych wyrobów (wytwarzanie i magazynowanie ich w ściśle określonym dla danego produktu zakresie temperatur i składzie sztucznie wytworzonej atmosfery) ${ }^{12}$.

Można z całą pewnością stwierdzić, iż koła militarne stworzyły sobie swoje sztuczne środowisko, w którym prowadzą szkolenie z użyciem sprzętu będącego na wyposażeniu oraz testują nową technikę wojskową. Potwierdzeniem analizowanych teorii może być historia wykorzystania GPS (Global Positioning System - 1973 rok powstania), który jest utrzymywany i zarządzany przez Departament Obrony USA. Na każdym satelicie zamontowana jest aparatura szpiegowska NUDET (Nuclear Detection) przeznaczona do natychmiastowego wykrywania wybuchów nuklearnych na Ziemi. Na dzień dzisiejszy jest 31 orbitujących satelitów ${ }^{13}$, które zapewniają przede wszystkim nawigację dla balistycznych rakiet międzykontynentalnych, a przeciętnemu człowiekowi GPS kojarzy się z nawigacją samochodową, może jeszcze czasami z geodezją i kartografią.

Dla ludzkości będzie najlepiej, żeby nigdy z tego środowiska nie wyszli (pełnili rolę straszaka w rękach polityków) a swoje zdobycze technologii przekazali społeczeństwu.

\section{WYKORZYSTANIE OSIĄGNIĘĆ ROZWIĄZAŃ ZE SZTUCZNEGO ŚRODOWISKA}

Prawdziwym poligonem opracowanych rozwiązań przez wojskowych są konflikty zbrojne. Do rozwoju chemii organicznej przyczyniła się II wojna światowa. Chemia polimerów spowodowała, że zanim kobiety ubrały pończochy nylonowe jako symbol seksapilu, z tego samego materiału szyte były spadochrony wojsk powietrzno-desantowych, które zrzucane były z powietrza na różnych obszarach działań zbrojnych. Mało kto dziś pamięta, że szkocki bakteriolog i lekarz Aleksander Fleming odkrywca pierwszego antybiotyku - penicyliny podczas pierwszej wojny światowej służył jako kapitan Korpusu Medycznego Brytyjskiej Armii Królewskiej ${ }^{14}$.

W świecie mody już od lat funkcjonuje pojęcie odzież militarna i autdoorowa. Te dwa segmenty mają wiele wspólnego z umundurowaniem współczesnego żołnierza. Ten drugi jak i użytkownicy cywilni cenią sobie swobodę ruchu, konieczność membranowego oddychania, możliwość szybkiego zwiększenia komfortu cieplnego przez dołożenie/zdjęcie ocieplacza/podpinki. Opisane przykłady rozwiązań w pierwszej wersji dla wojskowych z czasem wyciekają do zastosowań cywilnych.

12 J. Wasilczuk, M. Sobiech, A. Zieliński, Ekologiczne i ekonomiczne systemy ogrzewania, wentylacji oraz klimatyzacji pomieszczeń, WAT, Konferencja Naukowo-Techniczna na temat Inżynieria środowiska w budownictwie, Hel-Jurata 1993, s. 7-8.

13 https://pl.wikipedia.org/wiki/Global_Positioning_System (dostęp: 5.01.2017 r.).

${ }^{14}$ W roku 1944 Fleming otrzymał tytuł szlachecki, zaś w roku 1945 wraz z Howardem Floreyem i Ernstem Chainem Nagrodę Nobla w dziedzinie fizjologii i medycyny. http://odkrywcy.pl/ kat,1023503,title,Alexander-Fleming-odkrywca-penicyliny,wid,15406954,wiadomosc.html? smg4sticaid=61889a (dostęp: 30.01 .2017 r.). 
Chociaż w powszechnej świadomości wojsko oraz wojna nie powodują pozytywnych emocji, a zwykle kojarzą się ze zniszczeniem, to jednak należy powiedzieć o korzystnym aspekcie związanym ze zbrojeniami. Technologie wojskowe nie tylko trafiały do świata cywilów, ale czasami nawet go rewolucjonizowały.

\section{BADANIA WŁASNE}

Autorzy artykułu postanowili zająć się zbadaniem świadomości użytkowników osiągnięć już historycznych, jak i współczesnych technik i technologii statystycznego Polaka. Przygotowano ankietę, w której zapytano o pierwotne przeznaczenie dziś powszechnie wykorzystywanego sprzętu i rozwiązań ułatwiających codzienne życie.

Głównym celem przeprowadzonych badań ankietowych było poznanie poziomu świadomości respondentów dotyczącej wybranych urządzeń wykorzystywanych w codziennym funkcjonowaniu. Kto pierwszy był pomysłodawcą wybranych przykładów urządzeń, z którymi stykamy się na co dzień? Badania zostały przeprowadzone w kwietniu 2017 roku na Podkarpaciu i w Trójmieście.

U podstaw uogólnień opartych na danych empirycznych znajdują się dane cząstkowe, ze względu na to, że zazwyczaj nie jest możliwe zdobycie danych od wszystkich, których dotyczy dany problem badawczy. Badania ankietowe były dobrowolne i anonimowe. Dobór próby miał charakter celowy. W niniejszych badaniach uwzględniono cztery grupy w próbie badawczej:

I grupa - żołnierze pełniący służbę: na okrętach 5 (2 kobiety i 3 mężczyzn), w statkach powietrznych 5 (mężczyzn), mobilnej technice lądowej 5 (1 kobieta i 4 mężczyzn) i budowlach specjalnych 5 (2 kobiety i 3 mężczyzn);

II grupa - 20 pasażerów (po 10 kobiet i 10 mężczyzn) lotu (nie krótszego niż 3 godziny);

III grupa - 20 pracowników (po 10 kobiet i 10 mężczyzn) zatrudnionych w inteligentnym budynku zaprojektowanym i wykonanym po 2010 roku;

IV grupa - 20 gości (po 10 kobiet i 10 mężczyzn), którzy korzystali z usług hotelowych, nie krócej niż 2 doby o standardzie 5 gwiazdek.

Aby zastosować podstawowe założenia przyjmowane w nauce należy przyjąć warunki wstępne do prowadzenia naukowej dyskusji. Najbardziej istotną cechą procesu badawczego jest jego cykliczna natura. Najczęściej rozpoczyna się od postawienia problemu, a kończy wnioskami.

Problem główny w niniejszej pracy został sformułowany następująco:

Jaki jest poziom świadomości dotyczacej wybranych urządzén wykorzystywanych $w$ codziennym funkcjonowaniu?

Kwestionariusz ankiety został zredagowany w ten sposób, aby można było znaleźć odpowiedź na istotne problemy badawcze, które zostały ujęte w pytaniach szczegółowych:

- Kto pierwszy wykorzystat możliwości Internetu?

- Kto pierwszy zastosowat system GPS?

- Kto zapoczatkowat stosowanie klimatyzacji?

- Kto wprowadzit żywność o przedtużonym okresie do spożycia?

- Kto pierwszy wprowadzit/zastosowat nowe tkaniny do szeroko rozumianej konfekcji?

Do tak postawionych problemów badawczych można przedstawić następujące hipotezy. 
Hipoteza główna: Przypuszcza się, że poziom świadomości dotyczacej wybranych urządzeń wykorzystywanych $w$ codziennym funkcjonowaniu jest zróżnicowany w zależności od poszczególnych grup badawczych.

Można sądzić, ̇̇e wskazania I grupy badawczej, w której znaleźli się żotnierze będa bardziej adekwatne do rzeczywistości.

W odpowiedzi na problemy szczegółowe można uogólnić jedną hipotezę szczegółową, że odpowiedzi grupy II, III i IV będa posiadaty znacznie więcej wskazań niezgodnych z rzeczywistościa niż wskazania grupy $I$.

Pytania w kwestionariuszu ankiety były sformułowane w sposób jasny i zrozumiały. Miały charakter pytań zamkniętych, czyli respondenci w poszczególnych pytaniach mieli zbiory odpowiedzi, z których wybierali tę, która była zbieżna z ich wiedzą/poglądami.

$\mathrm{W}$ odpowiedzi na postawione $\mathrm{w}$ ankiecie pytania na wykresach zostały przedstawione odpowiedzi badanych.

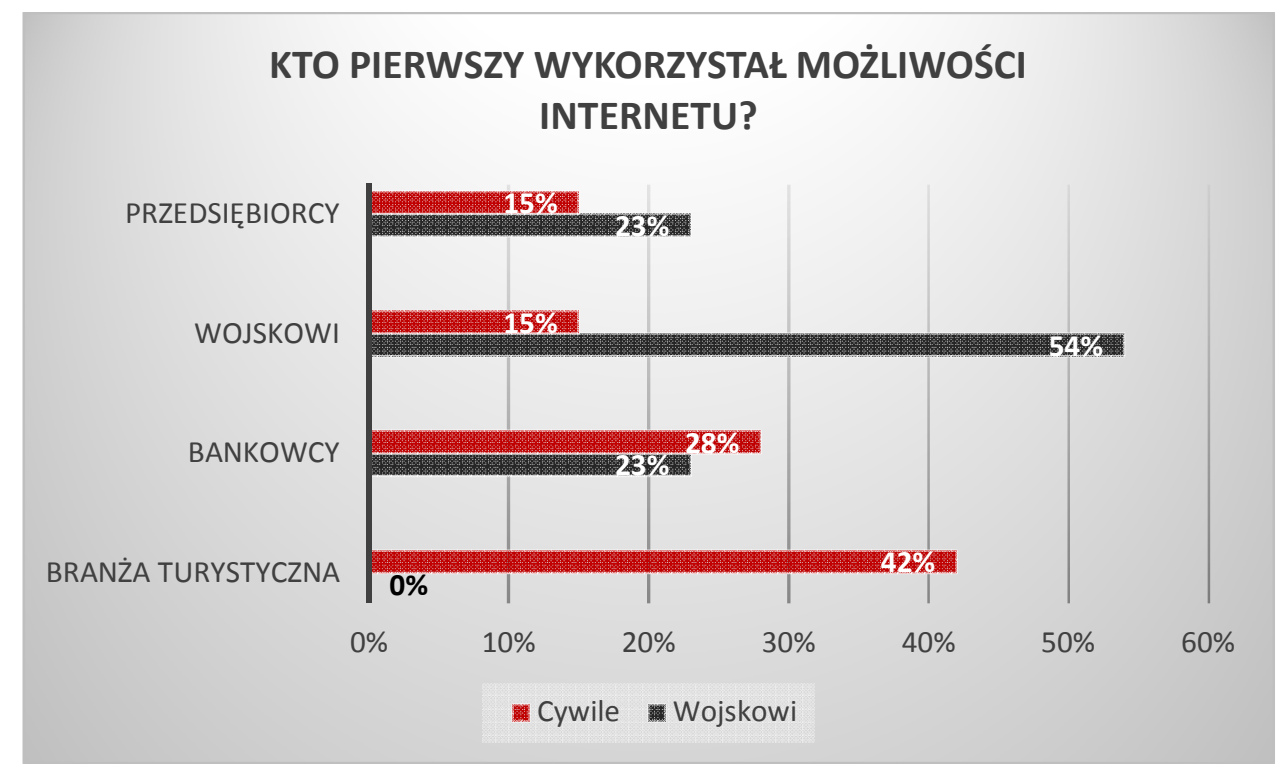

Wykres 1. Kto pierwszy wykorzystał możliwości Internetu?

Źródło: badania własne.

Jak obrazuje wykres 1, zdecydowana większość odpowiedzi wskazujących na pierwotne wykorzystanie Internetu przez wojskowych pojawiła się właśnie w ich odpowiedziach (54\%). Jednocześnie można się zastanawiać, dlaczego aż po $46 \%$ badanych wojskowych o tym fakcie nie wie i wskazuje przedsiębiorców (23\%) oraz bankowców (23\%). Nikt z ankietowanych wojskowych nie wskazał branży turystycznej.

Jeśli chodzi o wskazania badanych cywilów, to zdecydowana większość wybrała branżę turystyczną (42\%), a następnie bankowców (28\%). Natomiast po $15 \%$ wskazań było na przedsiębiorców i wojskowych. 
O ile brak świadomości wśród cywilów na temat pierwotnego wykorzystania Internetu można w jakiś sposób tłumaczyć, o tyle niski poziom świadomości w tym zakresie występujący wśród ankietowanych wojskowych może zastanawiać.

Na wykresie 2 bardzo wyraźnie widać dwa wskazania. Pierwsze z nich dotyczy wyboru wojskowych, którzy na postawione pytanie wybrali w $83 \%$ odpowiedź, że pierwotnie GPS wykorzystywali właśnie wojskowi. Jeśli chodzi o cywilnych respondentów, to tylko $7 \%$ z nich ma świadomość, kto pierwszy wykorzystywał system GPS.

Druga wyróżniająca się odpowiedź dotyczy wskazań badanych cywilów, którzy zaznaczyli branżę motoryzacyjną w $82 \%$.

Pozostałe wskazania mają małe znaczenie. Po $10 \%$ w poszczególnych grupach badanych wskazało na branżę turystyczną.

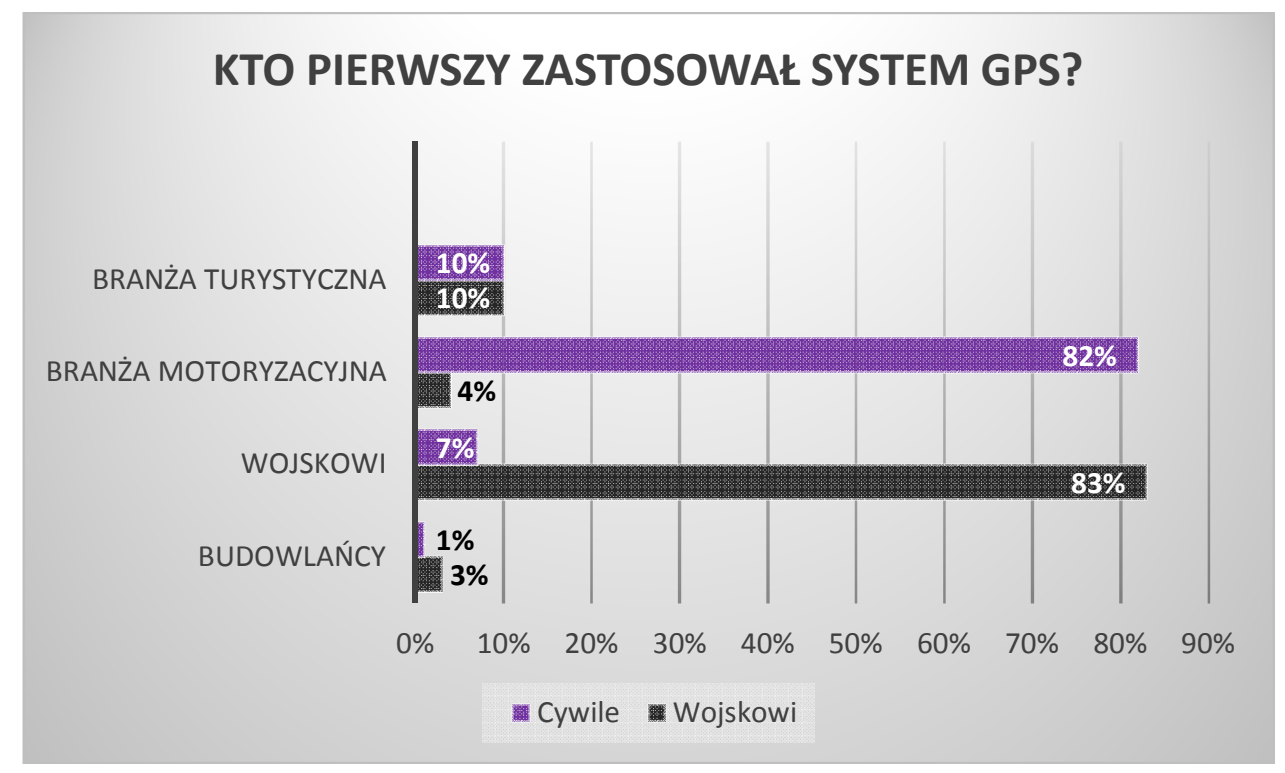

Wykres 2. Kto pierwszy zastosował system GPS?

Źródło: badania własne.

Zamieszczone na wykresie 2 odpowiedzi respondentów świadczą o znikomej świadomości cywilów w kwestii pierwotnego wykorzystywania systemu GPS. Natomiast wojskowi respondenci w zadowalającym procencie wskazali właściwą branżę.

Wybory respondentów w kwestii zapoczątkowania stosowania klimatyzacji nie są jednoznaczne. Cywilni badani najczęściej zaznaczali branżę budowlaną (52\%), następnie przemysł motoryzacyjny (35\%), wojskowy (8\%) i przedsiębiorców (5\%).

Jeśli chodzi o badanych wojskowych, to ich wybory kształtują się następująco: na swoją branżę wskazało 43\%, na branżę motoryzacyjną $37 \%$ i na budowlaną $20 \%$. Nikt z wojskowych nie wskazał na wykorzystanie klimatyzacji przez przedsiębiorców. 


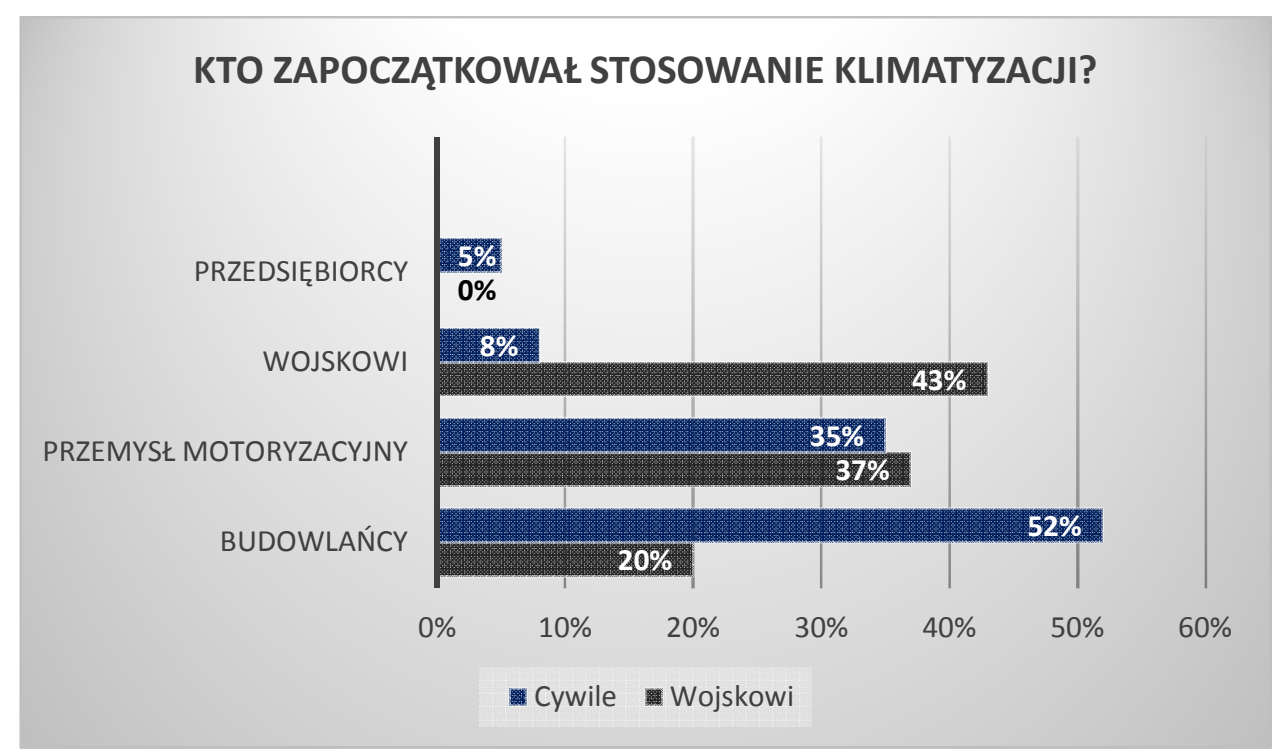

Wykres 3. Kto zapoczątkował stosowanie klimatyzacji?

Źródło: badania własne.

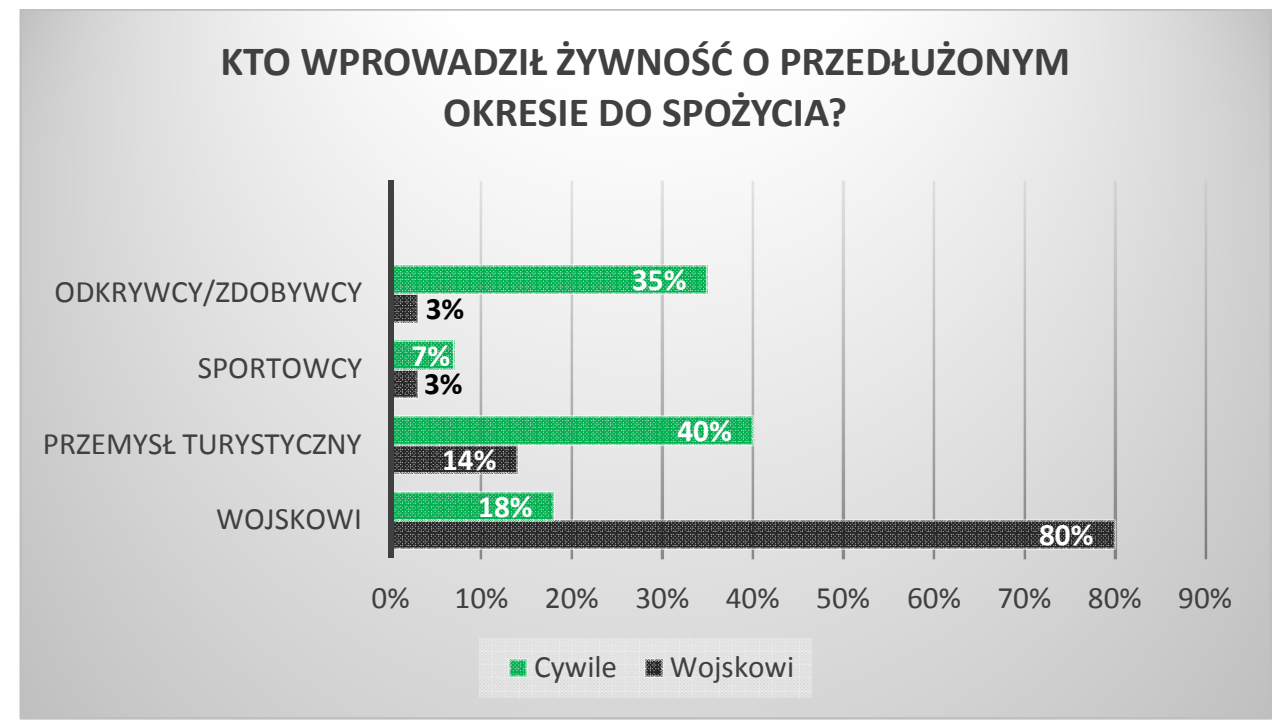

Wykres 4. Kto wprowadził żywność o przedłużonym okresie do spożycia?

Źródło: badania własne

Wykres 4 zdominowany został przez wskazania wojskowych na swoją branżę w kwestii wprowadzenia żywności o przedłużonym okresie do spożycia, aż 80\%. Można też 
powiedzieć, że w miarę znaczący odsetek badanych wojskowych wskazał na przemysł turystyczny $(14 \%)$ i mało istotne wskazania wojskowych po $3 \%$ na przemysł sportowy oraz odkrywców/zdobywców.

Odpowiedzi cywilów są podzielone i nie wskazują jednoznacznie branży, która jako pierwsza zaczęła stosować żywność o przedłużonym okresie do spożycia. 40\% w swoich odpowiedziach wybrało przemysł turystyczny, 35\% zaznaczyło zdobywców/odkrywców, $18 \%$ wojskowych i $7 \%$ sportowców.

Na wykresie 5 widać bardzo zróżnicowane odpowiedzi respondentów w kwestii odpowiedzi na pytanie, kto pierwszy zastosował nowe tkaniny do szeroko rozumianej konfekcji? Każda branża była wskazywana zarówno przez wojskowych jak i cywilów w dużym procencie. Najwięcej wskazań było wśród cywilów na branżę modową (40\%), następnie $35 \%$ wskazało wojskowych, $14 \%$ odkrywców/zdobywców/surwiwalowców i 11\% przemysł turystyczny.

Jeśli chodzi o wybory wojskowych, to najwięcej odpowiedzi padło na własną branżę (33\%), 28\% na odkrywców/zdobywców/surwiwalowców, 23\% na przemysł modowy i $16 \%$ na przemysł turystyczny.

Niewątpliwie tak różnorodne i w miarę wysokie wskazania zarówno wśród wojskowych, jak też cywilów w kwestii zastosowania nowych tkanin do szeroko rozumianej konfekcji mogą zastanawiać.

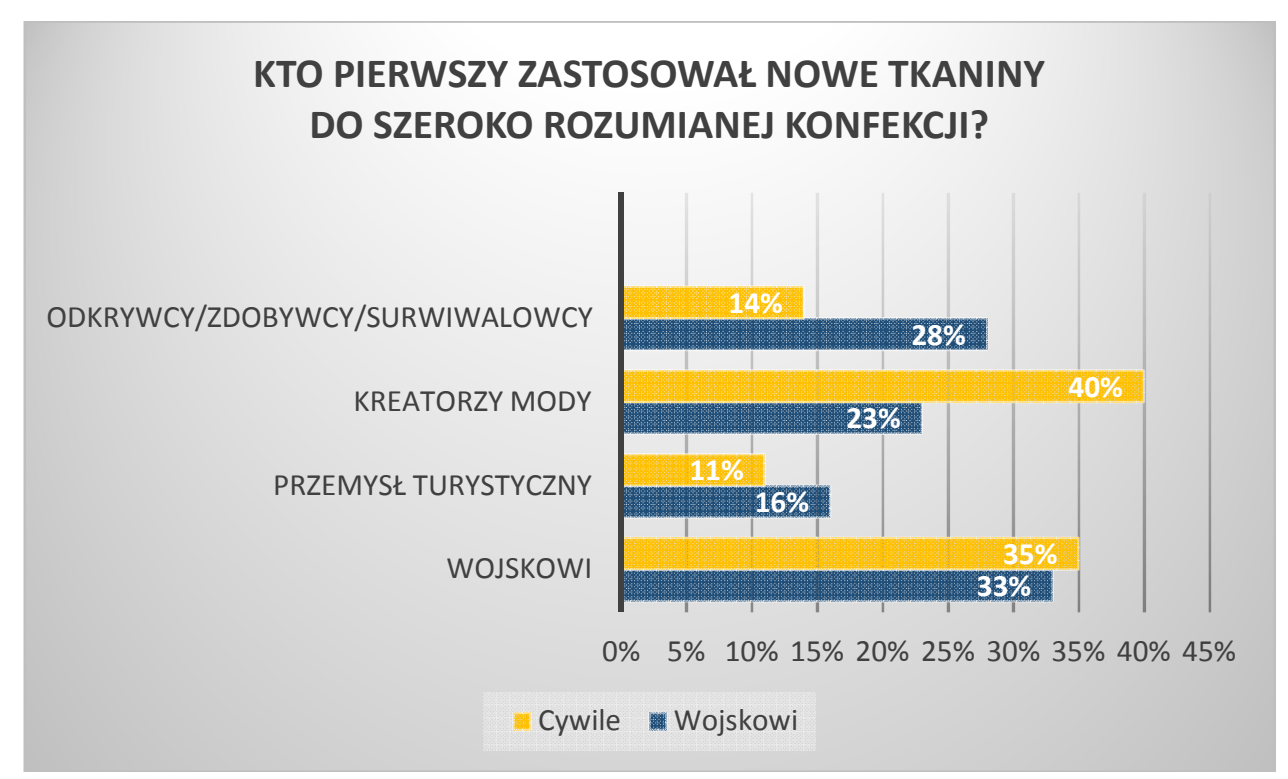

Wykres 5. Kto pierwszy zastosował nowe tkaniny do szeroko rozumianej konfekcji?

Źródło: badania własne.

Jak pokazują wyniki przeprowadzonych badań ankietowych, świadomość społeczeństwa na temat korzystania z wybranych składowych sztucznego środowiska militarnego jest na niskim poziomie. Zarówno badani cywile, jak i wojskowi nie zawsze zdają sobie 
sprawę z pierwotnego wykorzystywania urządzeń, z których korzystają na co dzień. Wiedza w tym zakresie ankietowanych wojskowych jest trochę większa, ale też jej poziom może zastanawiać. Nie każdy zdaje sobie sprawę, również wojskowi (tylko 54\%), że jeden z największych wynalazków ludzkości powstał z inicjatywy Amerykańskich Sił Zbrojnych. Ówczesna sieć ARPANET miała umożliwić wojsku niezależną komunikację.

\section{ZAKOŃCZENIE}

Można wskazać wiele technologii, które były wynalezione na potrzeby wojska, a zrewolucjonizowały życie cywili na całym świecie. To, czego my używamy dzisiaj na co dzień, pierwotnie wykorzystywali żołnierze.

Abstrahując od prawdziwości stwierdzenia, że to właśnie wojna jest matką wynalazków, a nie potrzeba, należy podkreślić, iż nasze codzienne życie bez wykorzystywania technologii wojskowych byłoby zupełnie inne.

Szybki rozwój technologii wojskowych oraz badań związanych z wykorzystaniem nowoczesnych wynalazków w obszarze zbrojeń w poprzednich dekadach spowodował wykorzystanie tych rozwiązań w codziennym życiu. Militarnie uwarunkowane badania pozwalają nie tylko zapewnić bezpieczeństwo, ale również nowe wynalazki ułatwiają funkcjonowanie społeczeństw.

Pogodzenie interesów wojska i nauki jest we współczesnym świecie działaniem oczywistym. Wiele osób uważa armię świata za wielkiego beneficjenta nauki, czerpiącego korzyści z rozwoju naukowego. Wspólne wysiłki wpływają na poprawę komfortu życia człowieka. Technologie podwójnego zastosowania, które są wykorzystywane zarówno w wojsku jak też w codziennym życiu mogą stać się szansą dla nauki i gospodarki.

\section{Literatura}

[1] Kaczmarek M., Stokwisz M., Wentylacja w budowli specjalnej, Wojskowa Akademia Techniczna, Konferencja Naukowo-Techniczna na temat Inżynieria środowiska w budownictwie, Hel-Jurata 1993.

[2] Wasilczuk J., Sobiech M., Zieliński A., Ekologiczne i ekonomiczne systemy ogrzewania, wentylacji oraz klimatyzacji pomieszczeń, Wojskowa Akademia Techniczna, Konferencja Naukowo-Techniczna na temat Inżynieria środowiska w budownictwie, Hel-Jurata 1993.

[3] Zakrzewski G., Czy sztuczne środowisko militarne jest faktem?, „Przegląd Morski” 1995/12.

[4] Żukowski P., Współczesne problemy ochrony środowiska człowieka, Uniwersytet Szczeciński, Szczecin 1985.

[5] Rozporządzenie Ministra Obrony Narodowej z dnia 3 kwietnia 2014 r. w sprawie stref zamkniętych dla żeglugi i rybołówstwa na obszarach morskich Rzeczypospolitej Polskiej (Dz.U. z 2014 r., poz. 482).

[6] Ustawa z dnia 21 marca 1991 r. o obszarach morskich Rzeczypospolitej Polskiej i administracji morskiej (tekst jedn. Dz.U. z 2016 r., poz. 2145 ze zm.).

[7] https://pl.wikipedia.org/wiki/Global_Positioning_System

[8] http://www.szkolnictwo.pl/szukaj,Jurij_Gagarin

[9] http://www.bhmw.mw.mil.pl/index.php?akcja=ostrzezenia

[10] http://www.wikiwand.com/pl/Poligon_wojskowy 
[11] http://odkrywcy.pl/kat,1023503,title,Alexander-Fleming-odkrywca-penicyliny,wid, 15406954, wiadomosc.html?smg4sticaid=61889a

\section{DETERMINING THE AWARENESS LEVEL OF USING SELECTED COMPONENTS OF ARTIFICIAL MILITARY ENVIRONMENT}

In this article the authors discuss the issue of "artificial military environment" taking into account the use of its achievements to enhance the standard and comfort of living in objects that are not connected with military technology and equipment or defense engineering. The prototype of the military milieu must be seen in mankind's first construction of palisades around its habitats. By modifying the habitat and its position for many years, by transferring it to a foreign not yet developed environment, the man developed it technologically more and more according to the socio-economic level.

The authors will look into this "artificial" environment taking into consideration the issues and directions of investigations from the military point of view. Following the history of the military we cannot resist the impression that the fighters evolving from the knight to the soldier have always cared not only for the development of martial arts, but they also paid much attention to arms, mobile and static military equipment and structures. It is no secret that before any invention is used by "civilians", its usefulness is first being examined by the military in order to determine its functionality to the broadly understood state of defense.

The history of using military achievements and introducing them to civil life will be presented in this article by following the specialist and industry literature of the subject and presenting the results of research that has been carried out on target groups distinguished from regions that the statistical Polish associates with broadly understood national defense.

Keywords: human environment, artificial military environment

DOI: $10.7862 / \mathrm{rz} .2017 . \mathrm{mmr} .46$

Tekst złożono w redakcji: październik 2017 r.

Przyjęto do druku: styczeń 2018 r. 